\author{
Adam Szelag \\ Tadeusz Maciolek \\ Zbigniew Drą̇ek \\ Marek Patoka \\ Politechnika Warszawska \\ Zakład Trakcji Elektrycznej
}

\title{
Aspekty efektywności i energooszczędności w procesie modernizacji układów zasilania trakcji tramwajowej
}

\begin{abstract}
Elektryczne hamowanie odzyskowe jest obecnie powszechnie stosowane w pojazdach trakcyjnch. Wprowadzanie do ruchu nowoczesnego taboru wyposażonego $w$ takie uktady $w$ istniejacych systemach tramwajowych powinno być poprzedzone analizami wymagań $i$ konieczności ewentualnych modernizacji, jakich należy dokonać w urzadzeniach infrastruktury elektroenergetycznej systemu transportowego. W referacie przedstawiono metodyke analiz w celu wyboru rozwiazań technicznych, w tym zastosowanie zasobników energii, które pozwalaja zwiększyć efektywność energetyczna wprowadzenia taboru z rekuperacja na istniejace linie tramwajowe. Załaczono przyktadowe wyniki $i$ wnioski z prac studialnych wykonanych przez autorów.
\end{abstract}

\section{Wprowadzenie}

Modernizacja układów zasilania systemu zelektryfikowanego transportu miejskiego jest zagadnieniem złożonym, niekiedy nawet trudniejszym niż budowa nowego systemu ze względu na konieczność wykonania zmian $\mathrm{w}$ istniejącej infrastrukturze, projektowanej dla zupełnie innych założeń ruchowych i klasycznego taboru. Dlatego uzasadnione jest zastosowanie kompleksowego podejścia i przeprowadzenia analizy funkcjonowania systemu $\mathrm{z}$ wydzieleniem podsystemów (tabor, zasilanie, ruch) oraz określeniem wzajemnych sprzężeń (więzi) pomiędzy nimi. Dla podsystemu zasilania istotnymi zagadnienia będą:

-charakterystyka potoków ruchu i intensywność przewozów,

-typy eksploatowanego taboru (masa, pojemność, prędkości maksymalne),

-charakterystyka tras (profile, łuki, przystanki, skrzyżowania kolizyjne),

-układ urbanistyczny obszaru objętego zasięgiem trakcji tramwajowej,

-konfiguracja publicznej sieci elektroenergetycznej,

-charakterystyka intensywności ruchu kołowego na trasach tramwajowych,

-zakładana prędkość jazdy pociagów tramwajowych.

Analizę funkcjonowania systemu zasilania przeprowadza się w przypadkach:

-projektowania nowych linii,

-odnowy lub rehabilitacji istniejących systemów ze względu na ich wyeksploatowanie, -modernizacji linii istniejących w przypadku wzrostu przewozów, wymiany taboru na tabor o innych parametrach (większe moce zainstalowane lub ostrzejsze wymagania co do poziomu napięcia w sieci trakcyjnej),

-konieczności określenia granicznej zdolności przepustowej systemu zasilania dla zmiennej (rosnącej) intensywności ruchu lub zwiększonych mocy.

Współczesne układy zasilania miejskiej trakcji tramwajowej w Polsce stanowią stadium rozwojowe $\mathrm{z}$ początków tramwaju elektrycznego w Europie na przełomie XIX i XX wieku. Dominuja zcentralizowane układy zasilania zapoczątkowane w okresie, kiedy przedsiębiorstwo tramwajowe było właścicielem wydzielonej elektrowni. Struktura $\mathrm{z}$ centralnie zlokalizowanym źródłem zasilania została w praktyce utrzymana do dzisiaj, z tym że w miarę rozprzestrzeniania się miast (aglomeracji) powielano ją wielokrotnie budując wraz $\mathrm{z}$ rozwojem sieci przesyłowych energetyki zawodowej w miejsce własnych elektrow$\mathrm{ni}$, prostownikowe podstacje trakcyjne zasilane z publicznej sieci elektroenergetycznej. Każda z tych podstacji trakcyjnych zasila przypisany jej rejon, sąsiadując $\mathrm{z}$ innymi podstacjami położonymi 'centralnie'(rys.1). Obszary stanowią autonomiczne czesści systemu nie współpracujące ze sobą nawzajem. Dzieje się tak za sprawą tradycyjnie przyjętego $\mathrm{w}$ trakcji tramwajowej jednostronnego systemu zasilania . Bardziej nowoczesny i mający wiele zalet $\mathrm{w}$ stosunku do systemu zcentralizowanego system 'liniowy', wdrożony w wielu krajach rozwiniętych, w którym odcinki zasilane są dwustronnie, dotychczas się w Polsce nie przyjął. 


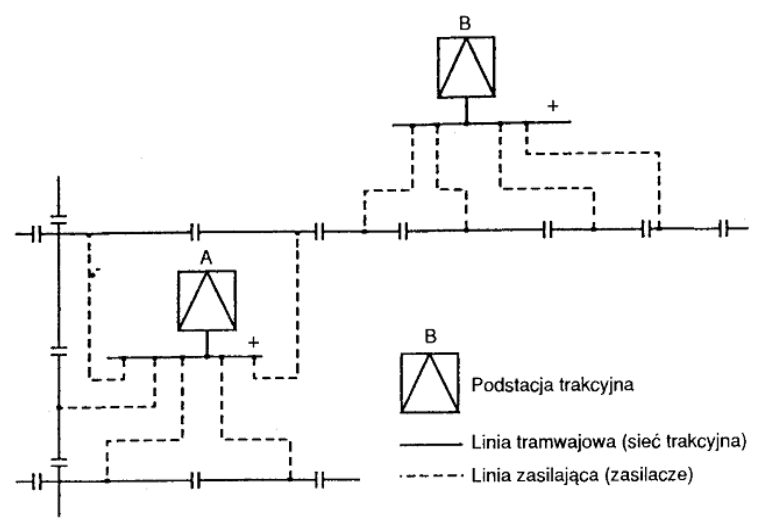

Rys.1 Podstacje zasilające sieć tramwajową w układzie: A centralnym, B-liniowym

\section{Kryteria wymiarowania układów zasilania trakcji tramwajowej.}

Podstawowym zadaniem układu zasilania jest dostarczenie energii o wymaganych parametrach do pojazdów znajdujących się $\mathrm{w}$ obszarze zasilania, a także w przypadku eksploatowania taboru trakcyjnego $\mathrm{z}$ hamowaniem rekuperacyjnym, zapewnienie możliwości przesyłu energii rekuperacji pomiędzy pojazdami. Prawidłowo zaprojektowany układ powinien spełniać wymagania efektywnego zasilania pojazdów w zakresie:

- utrzymania niezależnie od pobieranej mocy (w przedziale mocy roboczych) minimalnego napięcia na pantografie:

- chwilowego: $\mathrm{U}_{\mathrm{p}}\left(\mathrm{t}_{\mathrm{i}}\right) \geq \mathrm{U}_{\text {min }}$;

- Średniego : $\mathrm{U}_{\text {pśr }}\left(\mathrm{t}_{\mathrm{i}}\right) \geq \mathrm{U}_{\text {min }}$;

- utrzymanie niezależnie od pobieranej lub oddawanej (rekuperacja) mocy roboczej dopuszczalnego maksymalnego napięcia na pantografie:

- chwilowego: $\mathrm{U}_{\mathrm{p}}\left(\mathrm{t}_{\mathrm{i}}\right) \leq \mathrm{U}_{\max }$;

- średniego: $\mathrm{U}_{\text {psr }}\left(\mathrm{t}_{\mathrm{i}}\right) \leq \mathrm{U}_{\text {śrmax }}$;

(łącznie z przepięciami komutacyjnymi - wg PN-EN 50163)

- ograniczenia napięcia (potencjałów) szynowej sieci powrotnej i elementów uszynionych w stosunku do otaczającej ziemi i uziemionych części (ze względu na warunki bezpieczeństwa i ograniczenie prądów bładzących).

W celu wyznaczenia przekrojów elektrycznych torów prądowych obwodu głównego układu zasilania niezbędna jest znajomość następujących parametrów prądów obciążeń:

- maksymalne szczytowe prądy zastępcze (średniokwadratowe) ze względu na nagrzewanie oraz straty energii i sprawność,

- maksymalne chwilowe prądy robocze ze względu na dobór nastaw wyłączników szybkich i określenie maksymalnych dopuszczalnych rezystancji obwodu (przekroje przewodów i długości odcinków zasilania) dla przepływu dopuszczalnych minimalnych prądów zwarcia:

$$
\mathrm{I}_{\mathrm{zwmin}} \geq \mathrm{I}_{\mathrm{obcmac}}+\Delta \mathrm{I}
$$

gdzie:

$\Delta \mathrm{I}$ - margines bezpieczeństwa pomiędzy wartościami prądu zwarcia (minimalnego) i obciążenia (maksymalnego) uwzględniający fluktuację napięć zasilających, sezonowe zmiany rezystancji (w tym rezystancji szyny-ziemia), stabilność nastaw wyłączników szybkich oraz rozkład wartości chwilowych prądów obciążenia w funkcji liczności ich występowania (obszar prądów o dużych wartościach).

Moc zainstalowana $\mathrm{P}_{\text {Nins }} \mathrm{W}$ podstacjach trakcyjnych powinna spełniać warunek:

$$
P_{\text {Ninst }} k_{p}+P_{R} \geq\left\{\sum_{k=1}^{n} P\right\} \max
$$

gdzie:

$\mathrm{k}_{\mathrm{p}}$ - współczynnik przeciążalności szczytowej urządzeń układu zasilania,

$\mathrm{P}_{\mathrm{R}}$ - zainstalowana moc stanowiąca rezerwę,

$\mathrm{P}_{\mathrm{k}}$ - moc pobierana przez pojazd $\mathrm{w}$ okresie szczytu ruchowego,

n - największa spodziewana liczba pojazdów znajdujących się jednocześnie w obszarze zasilania podstacji trakcyjnej w okresie szczytu.

Długości odcinków zasilania sieci jezdnej, położenie punktów rozpływu prądów i punktów powrotnych w sieci szynowej oraz długości kabli zasilających i powrotnych powinny spełniać wymagania dotyczące maksymalnych spadków napięć:

$$
\Delta U_{d o p} \geq I \cdot r \cdot L
$$

gdzie:

I - wartość prądu (odpowiednio chwilowa lub średnia za dany okres),

$\mathrm{r}$ - rezystancja jednostkowa toru prądowego

L - długość toru prądowego (odcinka) .

Maksymalne długości odcinków kabli i sieci trakcyjnej są ograniczone przez ich przekroje oraz wartości przesyłanych prądów. Liczba zasilanych z jednej podstacji odcinków ograniczona jest mocą zainstalowanych prostowników oraz zdolnością przesyłu mocy przez linie elektroener-getyczne SN. Moce zwarciowe na szynach zbiorczych AC podstacji trakcyjnych nie powinny być niższe niż 120 MVA przy zasilaniu jednej podstacji, zaś przy grupie podstacji nie mniej niż 140-180MVA.

\section{Metodyka projektowania}

Wymiarowanie urządzeń zasilania elektrycznej trakcji tramwajowej stanowi część procesu projektowania nowego systemu transportu zelektryfikowanego lub modernizacji systemu dla przewidywanej zmiany warunków ruchowych (nowy tabor, prędkości, częstotliwość ruchu, rozmieszczenie przystanków). Celem 
jest dostosowanie tworzonego układu zasilania do możliwości wykonania zadania przewozowego aż do określenia granicznej zdolności efektywnego zasilania systemu zelektryfikowanego transportu miejskiego, przy maksymalnej granicznej wielkości ruchu pasażerskiego, prędkości komunikacyjnej oraz lokalizacji przystanków. Poszukuje się wariantów dających racjonalne, z punktu widzenia technicznego i ekonomicznego, rozwiązanie układu zasilania: liczby i typów zespołów prostownikowych w podstacji trakcyjnej, liczby zasilaczy, konfiguracji sieci zasilajacej (długości i przekroje kabli, lokalizacja punktów zasilania sieci trakcyjnej, sekcjonowanie) oraz rozwiązania struktury sieci powrotnej (długości i lokalizacja kabli powrotnych). Obszar, na którym operuje system komunikacji tramwajowej podzielony jest na rejony zasilania. Rozległość rejonów zasilania określa się według kryterium minimalnych kosztów inwestycyjnych i możliwości dostarczenia do pojazdu odpowiedniej energii oraz mocy (poziom napięcia na pantografie, niezawodność).

Podobnie dobiera się długości sekcji (odcinków) zasilania. Długość sekcji jest w ścisłej korelacji z wartościami maksymalnego spadku napięcia w sieci, maksymalnego prądu roboczego, oraz minimalnego prądu zwarcia.

W przypadku zbyt rozległych rejonów zasilania, np. gdy podstacja zasila kilka, nie stykających się ze sobą, odcinków sekcyjnych, oprócz dużych spadków napięć w sieci jezdnej mogą być zbyt duże spadki napięć w sieci szynowej, co jest przyczyną nadmiernego upływu prądu z szyn do ziemi (prądy błądzące).

Obliczenia parametrów układu zasilania opierają się na dwóch zasadniczych metodach, w zależności od przyjętego sposobu opisu obciążeń trakcyjnych:

- metoda zakładająca skupiony charakter obciążeń układu zasilania (dogodna do obliczeń odcinków o małej częstotliwości ruchu; dla różnych typów taboru znacznie różniących się między sobą parametrami trakcyjnymi),

- metoda zakładająca równomierność obciążeń na poszczególnych odcinkach zasilania (zwłaszcza w przypadku ruchu równomiernego o dużej częstotliwości kursowania, prowadzonego pojazdami o zbliżonych parametrach).

Pod względem funkcjonalnym metody obliczeń można podzielić na trzy grupy:

- metody klasyczne, wykorzystujące często zależności empiryczne,

dostosowane do określonych warunków ruchowych,

- obliczenia komputerowe bazujące na metodach sieciowych,

- symulacyjne obliczenia komputerowe - programy komputerowe wykorzystujące model systemu transportowego skojarzony $\mathrm{z}$ układem zasilania, w sposób dość wierny odzwierciedlający rzeczywiste warunki ruchu i zasilania.
Trzeci z wymienionych sposobów obliczeń znacznie różni się od pozostałych i sprowadza się do badań symulacyjnych $\mathrm{z}$ wykorzystaniem modelu układu komunikacyjnego zorientowanego na parametry energetyczno-ruchowe.

\section{Wymagania techniczne dotyczące zasilania elek- trotrakcyjnego dla taboru $z$ hamowaniem odzy- skowym}

Układ zasilania elektrotrakcyjnego powinien spełniać wymogi stawiane dla zasilania trakcji tramwajowej tak w warunkach normalnych jak i awaryjnych.

$\mathrm{Z}$ punktu widzenia układu zasilania istotne są tu:

-parametry podstacji trakcyjnej, -schematy sekcjonowania, -parametry sieci trakcyjnej, -parametry filtru wejściowego pojazdu,

- wyposażenie i sposób sterowania pojazdem.Jeśli w analizowanym systemie układu zasilania tramwaju odbiorcą energii hamowania odzyskowego mają być zasadniczo tylko inne pojazdy to odzyskiwana energia przy braku innych odbiorów będzie wytracana na rezystorach (hamowanie dynamiczne) lub gromadzona w zasobnikach (o ile będą stosowane).

Zalety zastosowania systemów hamowania odzyskowego to:

- zmniejszenie wydzielania ciepła w hamulcach mechanicznych lub rezystorach hamowania elektrycznego,

- zmniejszenie zużycia hamulców ciernych i kół,

- zmniejszenie zanieczyszczeń (od hamulców ciernych),

- zmniejszenie zużycia energii i mocy szczytowej, obniżenie kosztów.

- zmniejszenie obciążenia podstacji i spadków napięć (szczególnie w godzinach szczytu),

- poprawa sprawności przesyłu energii i zmniejszenie kosztów zużycia energii.

Do wad rekuperacji należą:

- zwiększenie kosztów inwestycyjnych tak w taborze jak i w układach zasilania (wymagane większe przekroje sieci i kabli ze względu na wydłużanie sekcji i ułatwienie możliwości przekazywania energii hamowania odzyskowego z sekcji na sekcję poprzez kable zasilaczy), konieczność stosowania wyłączników szybkich niespolaryzowanych,

- zwiększenie zakłóceń w sieci zasilającej DC (dodatkowe harmoniczne),

- wymagania co do stosowania inteligentnych systemów w taborze i układach zasilania do identyfikacji zwarć i ich prawidłowej eliminacji.

Proces odzyskiwania energii hamującego pojazdu należy rozpatrywać globalnie, począwszy od taboru a kończąc na układzie zasilania. Konkretny tabor ma zwykle zdefiniowane warunki i wymagania co do 
poprawnej pracy, w tym hamowania odzyskowego. Zdolność pojazdu do oddania energii, określona poprzez jego charakterystyki nie jest warunkiem wystarczającym do jej odzysku, niezbędny jest odbiornik tej energii o wymaganej zdolności jej wchłonięcia jak i układ zasilania zdolny do jej przesłania od pojazdu hamującego odzyskowo do pojazdu pobierającego energię.

Efektywność wykorzystania energii rekuperacji zależy od poziomu generowanego przez pojazd napięcia, liczby i położenia innych pojazdów, ich stanu pracy, stosunku czasu poboru energii do czasu ich znajdowania się na odcinku, długości sekcji i ich parametrów rezystancyjnych. Istotna jest także wartość rezystancji na drodze przepływu prądu rekuperacji, która zależy od schematu sekcjonowania, odległości między podstacjami, rezystancji jednostkowej szyny prądowej i szyn jezdnych, charakterystyki (pochylenia) podstacji trakcyjnej.

Można zwiększyć efektywność hamowania odzyskowego poprzez:

- wydłużenie sekcjonowanych obszarów zasilania (zasilanie wielostronne $\mathrm{z}$ kilku podstacji).

- zwiększenie różnicy napięcia pomiędzy napięciem na pantografie rekuperującego pojazdu $\mathrm{i}$ w najbliższej podstacji (zwykle napięcie rekuperacji ustalane jest na najwyższym możliwym poziomie, dlatego zwiększenie tej różnicy zasadniczo jest możliwe poprzez zmniejszenie napięcia podstacji (prostowniki sterowane),

- zmniejszenie rezystancji na drodze przepływu energii rekuperacji (zmniejszenie strat).

System zasilania powinien zatem być dostosowany nie tylko do zwiększonych obciążeń, ale również do wymagań współpracy z taborem nowego typu, wyposażonych w układy napędowe $\mathrm{z}$ silnikami asynchronicznymi i możliwością hamowania odzyskowego.

Typowo w trakcji tramwajowej stosowane jest zasilanie jednostronne. Wprowadzenie zasi-lania dwustronnego wymaga, dla zapewnienia prawidłowej pracy, spełnienia dodatkowych kryteriów takich jak:

- zachowanie ograniczonej wartości stosunku rezystancji współpracujących zasilaczy i podstacji ze względu na podział obciążeń pomiędzy zasilacze,

- wprowadzenia uzależnień pomiędzy współpracującymi zasilaczami w celu zapewnienia skutecznego wyłączania zwarć,

- przesekcjonowania sieci jezdnej i zmiana obwodów kabli zasilaczy i kabli powrotnych,

- wprowadzenia zdalnego sterowania i monitoringu. to:

Korzyści z wprowadzenia zasilania dwustronnego

- zmniejszenie maksymalnych wartości prądów obciążeń (możliwość niższych nastaw wyłączników szybkich),
- zmniejszenie prądów zastępczych (mniejsze obciążenia kabli),

- zmniejszenie strat przesyłowych w kablach i sieci jezdnej,

- zwiększenie niezawodności układu zasilania,

- możliwość kontroli mocy 15-minutowych i czasowego odciążenia podstacji lub stosowania rozliczeń sumacyjnych za pobieraną moc i energię.

\section{Modyfikacje istniejącego układu zasilania}

Istniejące w Polsce rozwiązania infrastruktury technicznej sieci tramwajów, budowane niekiedy ponad sto lat temu, nawet po późniejszych modernizacjach nie są zasadniczo dostosowane do zasilania taboru o podwyższonej mocy z rekuperacją energii. Powoduje to konieczność szczegółowego przeanalizowania warunków pracy systemu elektroenergetyki trakcyjnej ze względu na specyficzne wymagania tych pojazdów.

Zmiana struktury istniejących układów zasilania jest przedsięwzięciem kosztownym i wymaga-jącym istotnych ingerencji w infrastrukturę techniczną linii. Dlatego przy opracowywaniu wariantów modernizacji powinno się proponować rozwiązania, które zapewnią wymaganą efektywność techniczną i energetyczną przy maksymalizacji wykorzystania istniejącej infrastruktury układu zasilania i minimalizacji nakładów. Przykładowo, spośród różnych opcji w pracy 5] poddano analizie następujące warianty modyfikacji:

-połączenie poprzeczne przez w.sz (wyłącznik szybki) niespolaryzowany (zasilanie dwu-stronne w obrębie podstacji trakcyjnej PT)

-połączenie wzdłużne - na stałe (bez w.sz.) (zasilanie dwustronne w obrębie PT)

-połączenie wzdłużne - na stałe (bez w.sz.) (zasilanie dwustronne) z 2 PT

-przesunięcie izolatora

-przesunięcie przyłącza kabla powrotnego -przesunięcie przyłącza kabla zasilającego

-wydłużenie kabla zasilającego

-zainstalowanie zasobnika na tramwaju

-zainstalowanie zasobnika w PT

-zainstalowanie zasobnika w punkcie sieci (pętla),

- zainstalowanie rezystora wyrównawczego szeregowo z kablem powrotnym.

Ze względu na konieczność spełnienia wymagań dotyczących zarówno taboru, jak i efektywności zastosowania zasilania dwustronnego należało rozpatrywać typowe, występujące aktualnie schematy zasilania i możliwość ich adaptacji do wymagań zasilania zwiększającego efektywność rekuperacji energii tramwajtramwaj.

Jeden $\mathrm{z}$ typowych schematów jednostronnego zasilania sieci trakcyjnej przedstawiono na rys. 2 , zgodnie $\mathrm{z}$ nim można w dość prosty sposób uzyskać zasilanie dwustronne. W przypadku, gdy oba zasilacze są z tej 
samej podstacji łatwo (w sposób sprzętowy lub programowy, gdy stosowany jest sterownik CZAT) uzyskać uzależnienie w.sz. zasilaczy.

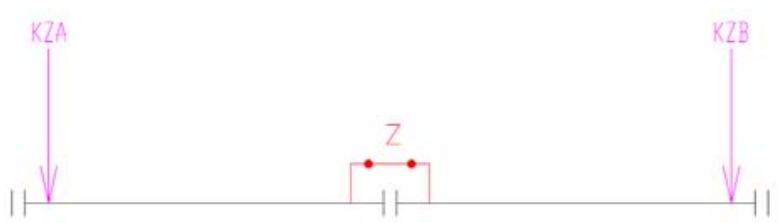

Rys.2 Zasilanie jednostronne dwóch sekcji sieci trakcyjnej na tym samym torze, zasilacze przy zewnętrznych izolatorach, sekcje o zbliżonych długościach, możliwość uzyskania zasilania dwustronnego poprzez zamknięcie odłącznika na izolatorze rozdzielającym sekcje.

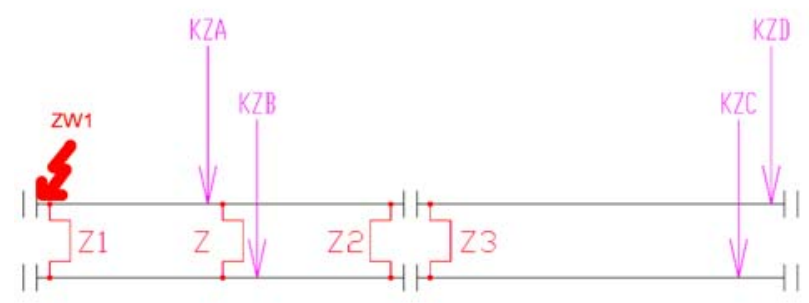

Rys.3 Zasilacze KZA i KZB zasilające sekcje sieci trakcyjnej różnych torów o tej samej długości (rezystancji), zasilacze KZB i KZD o różnych długościach (rezystancjach).

W przypadku przedstawionym na rys. 3 zasilacze KZA i KZB mają zbliżone rezystancje, zamknięcie odłącznika $Z$ spinającego sieć obu torów powoduje powstanie zasilania nadal jednostronnego, ale obciążenie rozkłada się na 2 zasilacze w miarę równomiernie (przy różnicach rezystancji nie większych niż 15$20 \%$ ), można jedynie obniżyć nastawy w.sz. ze względu na pracę jednoczesną obu zasilaczy z koniecznością ich uzależnienia. Dopiero zamknięcie odłącznika Z1 i Z2 powoduje powstanie zasilania dwustronnego w pętli, zmniejszenie spadków napięć i zwiększenie wartości minimalnych prądów zwarć w punkcie zwarcia.

\section{Przykładowe wyniki symulacji funkcjonowania układu zasilania}

Do kompleksowych analiz funkcjonowania układu zasilania zastosowano opracowany w Zakładzie Trakcji Elektrycznej Politechniki Warszawskiej dedykowany pakiet programów symulacyjnych. Uzyskane w wyniku symulacji obciążenia zasilaczy i podstacji zestawiono i poddano analizie. Dotyczyło to parametrów pozwalających na dobór poszczególnych urządzeń i elementów obwodów.

\section{1 Obciążenia podstacji trakcyjnej i zasilaczy}

Istotnym kryterium jest wykorzystanie mocy zainstalowanych $\mathrm{w}$ podstacjach przy założeniu pracy w różnych warunkach ruchowych, w tym skrajnych z uwzględnieniem spiętrzeń ruchowych (rys. 6). Zwykle przyjmuje się pracę N-1 zespołów prostownikowych

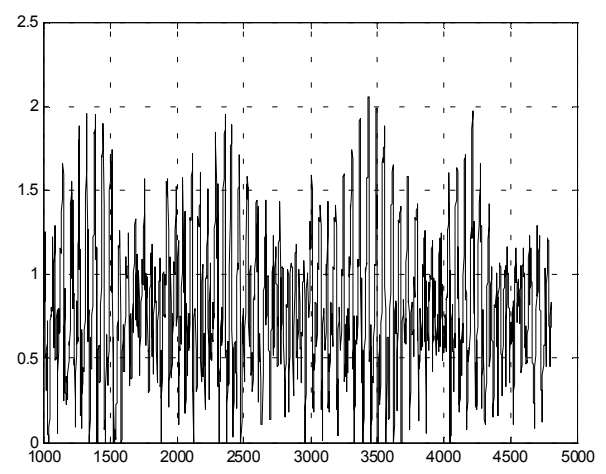

Rys. 4 Przykładowy przebieg mocy chwilowej podstacji (wynik symulacji)

W odniesieniu do zasilaczy i kabli powrotnych wyznaczono prądy zastępcze 15-min. (rys. 9), które w żadnym przypadku nie powinny przekraczać wartości dopuszczalnych (przyjęto jako kryterium graniczne $90 \%$ wartości dopuszczalnej dla danego zasilacza). W przypadku przekraczania tych wartości proponowano dokonanie zmian w układzie zasilania.

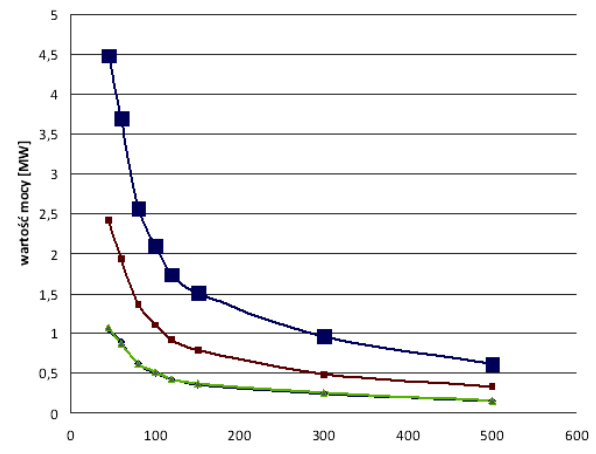

Rys. 5 Przykładowa zależność mocy zastępczych różnych podstacji w funkcji średnich następstw kursowania tramwajów (układ liniowy zasilania sieci trakcyjnej).

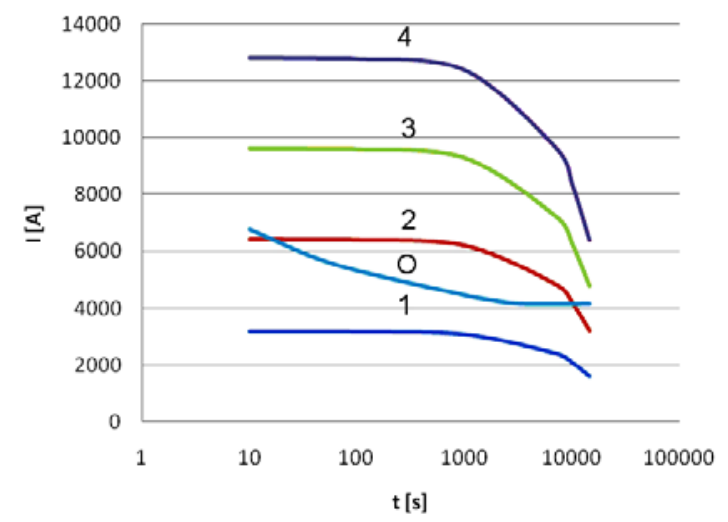

Rys. 6 Uporządkowane wartości prądów1) zastępczych podstacji (krzywa 0-wyniki symulacji) i krzywe dopuszczalnej obciążalności podstacji wyposażonej w 1,2,3 i 4 zespoły prostownikowe o prądzie znamionowym $1600 \mathrm{~A}$ (klasa V przeciążalności) 


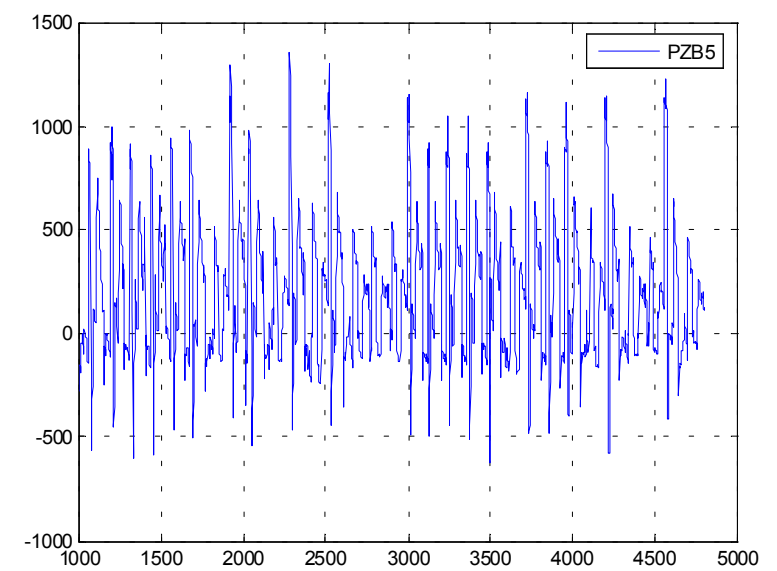

Rys. 7 Przebieg prądu chwilowego zasilacza

\subsection{Zwarcia}

Do obliczeń prądów zwarć przyjmuje się skrajne przypadki występowania warunków zwarciowych (1 pracujący zespół prostownikowy, spadek napięcia na łuku, obniżenie napięcia zasilania elektroenergetycznego o 10\%, 10\% zużycie sieci trakcyjnej), co powodowało, że wyznaczone wartości są zaniżone, dają jednak pogląd na możliwość występowania zagrożeń wystąpienia zwarć niewykrywalnych.

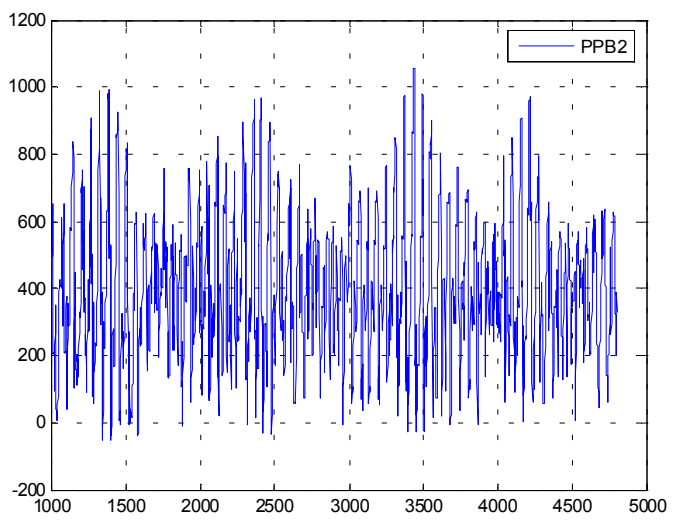

Rys. 8 Przykładowy przebieg prądu chwilowego kabla powrotnego

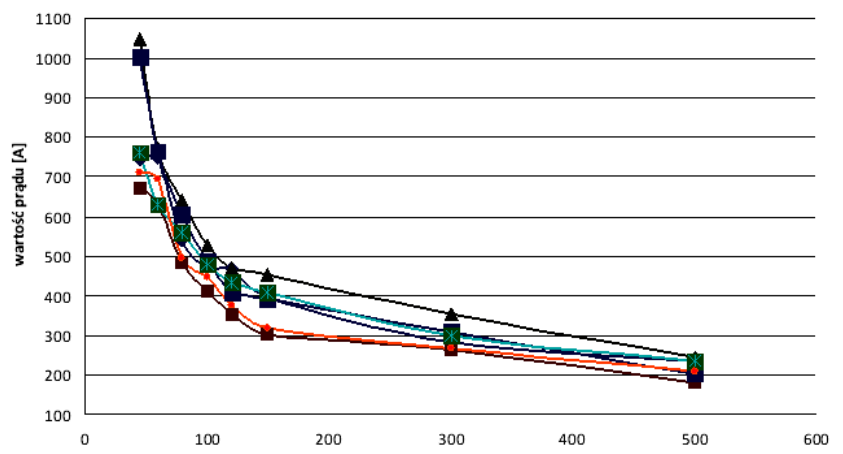

Rys. 9 Przykładowa zależność prądu zastępczego 15-min. zasilaczy w funkcji średniego następstwa tramwajów

W warunkach wzrostu udziału taboru z rekuperacją, szczególnie przy spiętrzeniach ruchowych, których występowanie ma w wielu przypadkach charakter losowy (w trakcie symulacji występowały takie przypadki), prądy maksymalne zasilaczy: mogą znacząco przekraczać 4kA.
Proponowano docelowe wprowadzenie zmian w układzie zasilania w przypadku występowania możliwości przekroczenia przez zasilacze wartości 4kA przy zbyt niskich wartościach minimalnych prądów zwarć. Zagadnie zadziałania w.sz. powinno być powiązane $\mathrm{z}$ doświadczeniami eksploatacyjnymi, a zmniejszenie prawdopo-dobieństwa ich wystapienia związane jest m. in. z wartością maksymalnych prądów tramwajów i regulacjami w zakresie rozładowywania spiętrzeń ruchowych lub ruchu w warunkach awaryjnych. Wobec uzyskanych informacji o wartościach maksymalnych prądów nowoczesnych tram-wajów, przekraczających 1,4kA, wydaje się uzasadnione zalecenie obniżenia tego prądu do 1-1,1kA. Nie powinno to mieć istotnego wpływu na parametry trakcyjno-ruchowe taboru, a w sposób zdecydowany zmniejszy prawdopodobieństwo zadziałania w.sz.. i pozwoli obniżyć nastawy w.sz. na odcinkach o zbyt niskich wartościach minimalnych zwarć.

\subsection{Napięcia w sieci trakcyjnej i potencjaly szyn jezdnych}

Wyniki symulacji pozwoliły na ocenę wartości napięć w sieci trakcyjnej. Napięcia na odbierakach taboru powinny mieścić się $\mathrm{w}$ granicach określonych normą PN-EN-50-163. Można tu zastosować podane $\mathrm{w}$ w/w normie kryterium napięcia użytecznego, które uwzględnia wartość napięcia chwilowego $\mathrm{z}$ wagą pobieranego prądu.

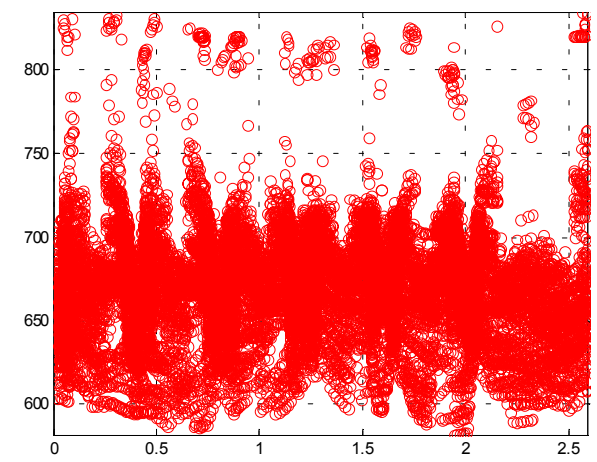

Rys. 10 Zestawienie wartości napięć chwilowych w sieci trakcyjnej w funkcji położenia tramwaju

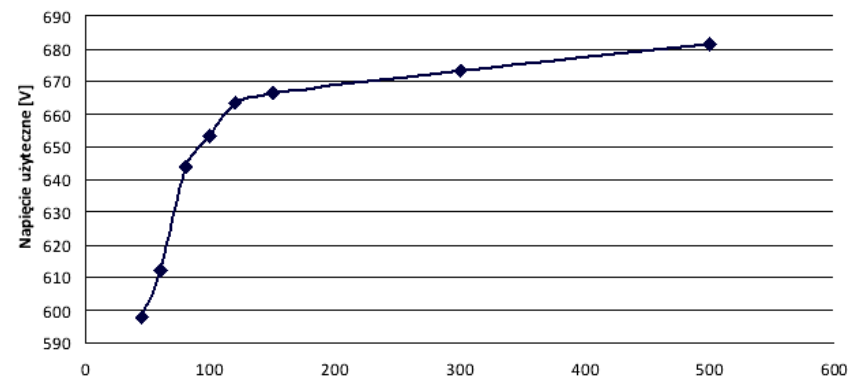

Rys. 11 Wartości napięć użytecznych w sieci trakcyjnej w funkcji średniego następstwa tramwajów 
Chwilowe potencjały szyn, nawet $\mathrm{w}$ przypadku zasilania w warunkach awaryjnych (ale nie zwarciowych) nie powinny przekraczać dopuszczalnych wartości ze względu na bezpieczeństwo (w miejscach publicznych: $60 \mathrm{~V})$.

W celu zapewnienia bezpieczeństwa na przystankach i innych miejscach o dużym dostępie dla pasażerów i osób postronnych zalecane jest stosowanie środki ochrony przewidzianych normą PN-EN 50-122-1, w tym uszynienia otwartego.

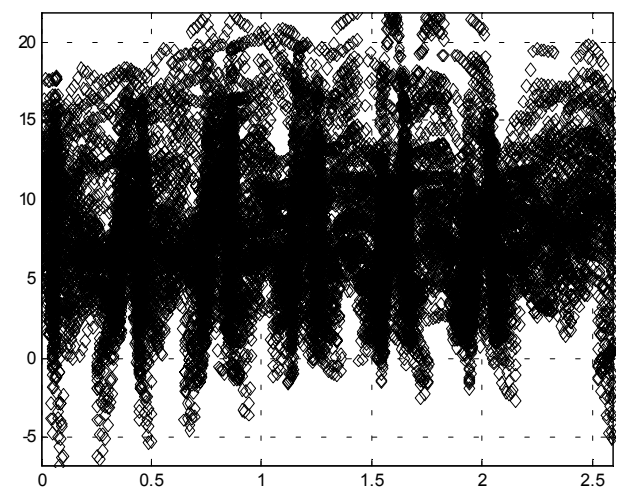

Rys.12 Chwilowe potencjały szyn w funkcji położenia tramwaju.

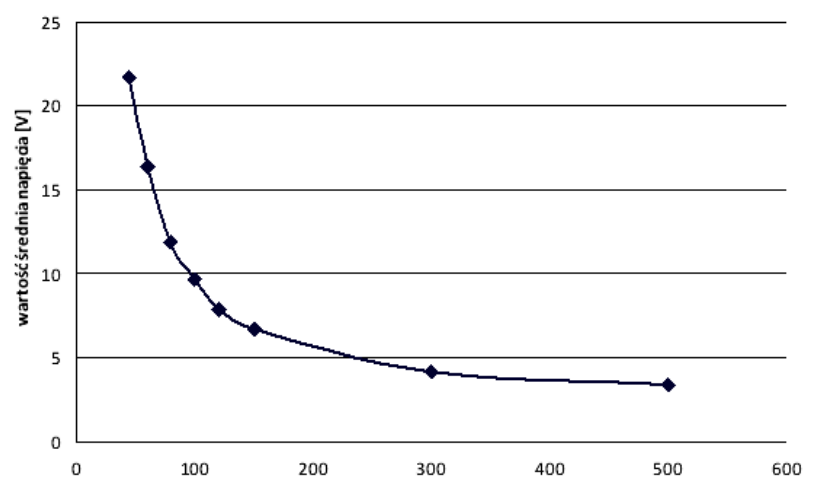

Rys. 13 Napięcia średnie szyn w średniego następstwa tramwajów

\subsection{Efektywność hamowania odzyskowego}

Zastosowanie przedstawionej metodyki analiz pozwala na dokonanie oceny efektywności hamowania odzyskowego $\mathrm{w}$ różnych konfiguracjach sieci zasilającej. Można do tego zastosować porównanie:

$>$ mocy średniej (energii) pobranej z podstacji i mocy pobranej przez pojazdy,

> relacji mocy średniej (energii) pobranej z podstacji trakcyjnej do energii dostarczonej do pojazdów trakcyjnych (rys. 14).W przypadku braku hamowania odzyskowego współczynnik ten pozwala określić straty energii $\mathrm{w}$ układzie zasilania i jest zawsze większy od 1, z kolei przy efektywnym hamowaniu odzyskowym może być mniejszy od 1, gdyż pojazdy tramwajowe przekazują sobie energię hamowania odzyskowego.
Porównanie tych parametrów pozwala na oszacowanie efektywności poszczególnych konfiguracji dokonywanych modernizacji i celowości ich wdrożenia.

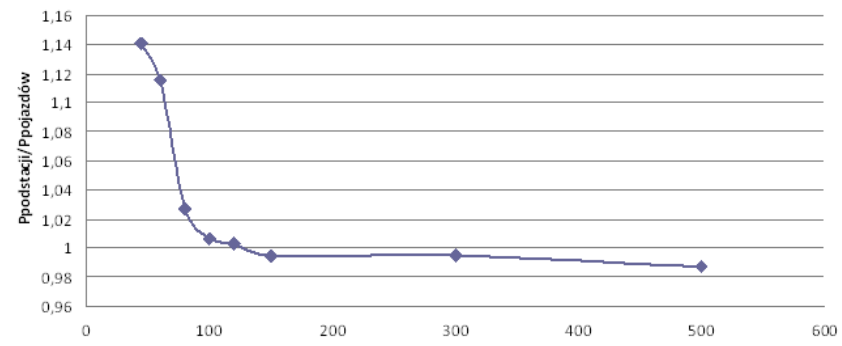

Rys. 14 Stosunek moc średnia podstacji/moc średnia pojazdów w funkcji następstwa tramwajów

\subsection{Oddziaływanie na infrastrukturę techniczną}

Zainstalowane $\mathrm{w}$ podstacjach trakcji miejskiej prostowniki są elementami nieliniowymi dużej mocy pobierającymi z systemu elektroenerge-tycznego prąd odkształcony, co wywołuje $\mathrm{z}$ kolei odkształcenie napięcia $w$ liniach zasilających. Jest to szkodliwe $\mathrm{z}$ punktu widzenia jakości energii dostarczanej do innych odbiorników wrażliwych na zasilanie napięciem odkształconym, może również powodować wystapienie rezonansów (długookresowe).

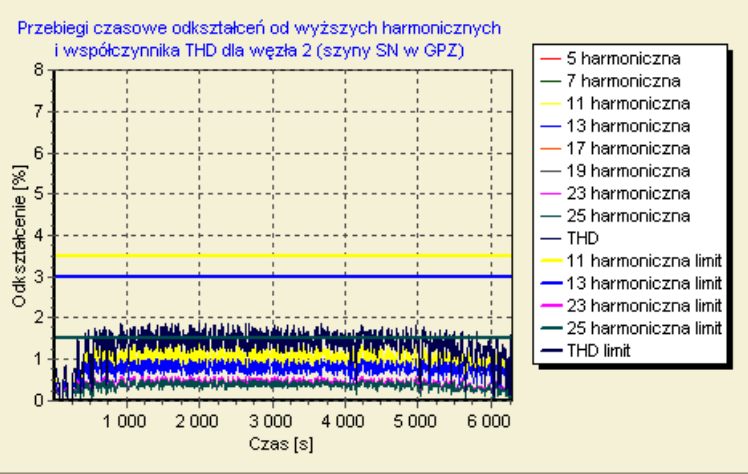

Rys.15 Przebieg odkształceń nieliniowych napięcia w funkcji czasu na szynach $15 \mathrm{kV}$ w GPZ (liniami zaznaczono limity).

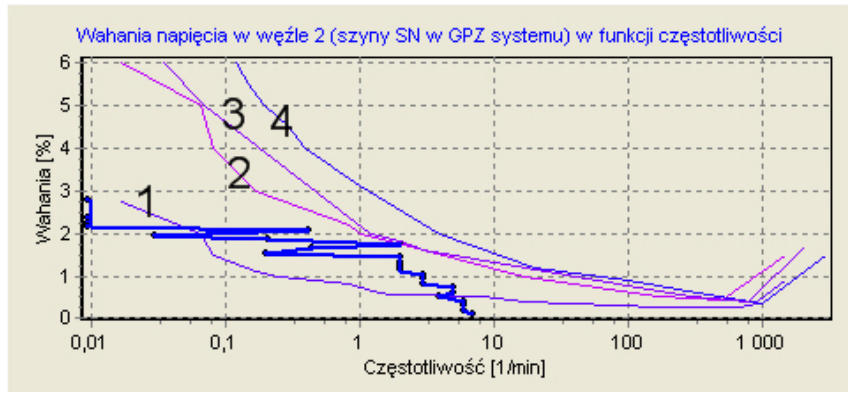

Rys.16 Wahania napięcia na szynach $15 \mathrm{kV}$ w GPZ w funkcji częstotliwości wystąpień (dla obciążenia podstacji) w porównaniu $\mathrm{z}$ różnymi kryteriami: 1 - kryterium percepcji wahań, 2 kryterium irytacji; 3, 4-inne kryteria 
Uzyskane w wyniku obliczeń symulacyjnych przebiegi obciążeń podstacji zostały wykorzystane do przeprowadzenia analiz oddziaływania podstacji trakcyjnych na sieć zasilająca (harmoniczne, wahania napięcia) i sprawdzenia spełniania wymaganych przepisów (Rozporządzenia Ministra Gospodarki z 4 maja 2007r. i normy EN50160). Określono wymagane warunki zasilania podstacji z sieci zasilającej, tak aby powyższe wymagania zostały spełnione.

\subsection{Wymagania w zakresie ochrony przed prądami błądzącymi}

Istotnym problemem eksploatacyjnym systemu tramwajowego $\mathrm{z}$ punktu widzenia układu zasilania są prądy błądzące. W aktualnej normie : PN-EN 50122-2: (wersja styczeń -2011) Zastosowania kolejowe. Urządzenia stacjonarne. Część 2: Środki ochrony przed oddziaływaniem prądów błądzących wywołanych przez trakcję elektryczną w wymaganiach ogólnych zwrócono uwagę na problem prądów błądzących oraz konieczność opracowania studium dotyczącego problemu prądów błądzących, które należy wykonywać wspólnie ze stronami, których to dotyczy.

Izolacja szyn jezdnych powinna być skoordynowana $\mathrm{z}$ innymi środkami ochrony, które zapewnia, że napięcia dostępne wytworzone przez trakcyjne prądy powrotne i napięcia dotykowe wytworzone przez prąd w przypadku awarii, nie przekrocza wartości dopuszczalnych, podanych w normie PN-EN 50122-1.

W porównaniu do poprzedniej wersji tej normy dodano stwierdzenie, że gdy średnia wartość napięcia w szynach (dla obciążenia średniorocznego) nie przekracza $5 \mathrm{~V}$ oraz konduktancja jednostkowa nie przekracza watości $0,5 \mathrm{~S} / \mathrm{km}$ (dla jednego toru) nie jest wymagane stosowanie innych środków ochrony od prądów błądzących.

\subsection{Zastosowanie zasobników energii}

W ostatnim okresie pojawiły się w Polsce superkondensatorowe zasobniki energii oferowane $\mathrm{m}$. in. przez Instytut Elektrotechniki w Warszawie. Dlatego uzasadnione jest $\mathrm{w}$ trakcie wykonywania studiów i analiz dot. układów zasilania rozpatrzenie celowości zastosowania zasobnika.

Zastosowanie zasobników energii w układzie zasilania lub na pojeździe pozwala na:

- zmniejszenie szczytów i wyrównywanie obciążeń dzięki zmniejszeniu zapotrzebowania na moc szczytową (zasobnik zaczyna oddawać moc przy wzroście zapotrzebowania). Może to dawać w efekcie zmniejszenie mocy zamawianej i zmniejszenie kosztów opłat za moc 15-min. i jej przekroczenia.,
- poprawę warunków napięciowych, dzięki zmniejszeniu obciążenia systemu, dzięki czemu zwiększa się sprawność i prędkość jazdy pociagów (charakterystyka trakcyjna zależy od napięcia),

- poprawę warunków dostawy mocy w przypadku awarii. Energia zgromadzona w zasobniku, dostarczona do pojazdów, pozwala na dojechanie pociągów do przystanku nawet w przypadku zaniku zasilania podstacji.

- wyrównywanie obciążeń w okresach zwiększonego zapotrzebowania na energię z systemu (gromadzenie energii $\mathrm{w}$ zasobniku gdy zapotrzebowanie na energię jest niewielkie $\mathrm{i}$ oddawanie $\mathrm{w}$ godzinach szczytu poboru z systemu elektroenergetycznego).

W zależności od umiejscowienia zasobnika możemy uzyskać następujące efekty:

zasobnik na pojeździe:

$>$ obniżony pobór mocy maksymalnej i obniżenie kosztów przyłączy

$>$ znaczne obniżenie poboru energii

$>$ zmniejszenie strat energii w sieci

$>$ w przypadku prowadzenia ruchu mieszanego (pojazdy nowego i starego typu) - możliwość transferu energii ze zwykłych pojazdów (nie wyposażonych $\mathrm{w}$ zasobnik) do zasobnika $\mathrm{w}$ tramwaju

$>$ w przypadku jednolitego taboru nowego typu - obniżenie kosztów inwestycyjnych w podstacjach i obwodach zasilania.

$>$ możliwe znaczne zmniejszenie nastaw wyłączników szybkich i możliwość eliminacji problemu wyłączalności zwarć dalekich.

$>$ zwiększenie trwałości elementów układu zasilania.

$>$ możliwe znaczne zwiększenie gęstości ruchu pojazdów bez modernizacji systemu zasilania.

$>$ zmniejszenie średniego i maksymalnego prądu w sieci powrotnej, co zmniejsza wartości prądów błądzących (w przypadku zasobnika w podstacji następuje wzrost wartości skutecznej prądów błądzących);

zasobnik w uktadzie zasilania:

> możliwość obniżenia maksymalnej mocy pobieranej z systemu elektroenergetycznego

$>$ możliwość zastosowania dowolnego typu zasobnika

$>$ wykorzystanie zasobnika dla istniejącego taboru

> wadą jest zależność wykorzystania zasobnika od udziału ruchu tramwajów z możliwością rekuperacji energii do sieci w ruchu całkowitym. Przy małej liczbie tramwajów z rekuperacją stopień wykorzystania zasobników jest niski. 
Przeprowadzone analizy [5] wykazały, że zastosowanie zasobników może być uzasadnione i zależy od typu taboru, częstości kursowania i konfiguracji układu zasilania. Szczególnie dotyczy to obszarów o niskiej gęstości ruchu lub o słabym układzie zasilania. Wtedy zasobnik może stanowić tzw. zastępczą podstację.

Dodatkową zaletą zastosowania zasobników jest stabilizacja napięcia $\mathrm{w}$ sieci, i to zarówno przy większych obciążeniach (zwiększenie napięcia) jak i przy rekuperacji (ograniczenie napięcia) oraz $\mathrm{w}$ stanach przejściowych (ograniczenie przepięć).

\section{Podsumowanie}

Wprowadzenie nowoczesnego taboru tramwajowego stanowi wyzwanie dla istniejącej infrastruktury tramwajowej. Aby uzyskać spodziewane efekty oszczędności energii należy poddać dość gruntownej analizie warunki funkcjonowania systemu tramwajowego i istniejących układów zasilania. W większości przypadków konieczne będą modernizacje w odniesieniu do poszczególnych odcinków zasilania i podstacji, mające na celu $\mathrm{z}$ jednej strony zapewnienie niezawodności funkcjonowania układu zasilania dla docelowego udziału taboru z rekuperacją, z drugiej strony zwiększenie efektywności wykorzystania hamowania odzyskowego i zmniejszenie zużycia energii. Prowadzone dla szeregu tras i linii analizy wykazały, że nawet przy stosunkowo niewielkich nakładach w modernizowanym układzie zasilania można uzyskać szybko zwracające się efekty (oszczędność energii i w efekcie zmniejszenie emisji $\mathrm{CO}_{2}$ ), umożliwić efektywne zasilanie nowoczesnego taboru oraz poprawić niezawodność zasilania poprzez zmniejszenie prawdopodobieństwa występowania zakłóceń i awarii.

\section{Literatura}

[1.] Drażek Z., Mierzejewski L., Szelag A.- Zasilanie dwustronne $w$ trakcji miejskiej. Technika Transportu Szynowego nr 2/1996, s.35-37

[2.] Szelag A. - Obliczanie tramwajowej sieci powrotnej w celu zmniejszenia uplywu z szyn jezdnych pradów bładzacych. Konf. N-T "Trakcja elektryczna w komunikacji miejskiej " TRAM'96, Gdańsk 9-11 V 1996, s.95-102

[3.] Szelag A. - Wymiarowanie granicznych zdolności przesylu energii $w$ sieci zasilajacej $i$ powrotnej trakcji tramwajowej. SEMTRAK'96, s. 289-298

[4.] Z. Drażek, L. Mierzejewski, A. Szelag-Obliczenia metodami analitycznymi parametrów sieci zasilajacej $i$ powrotnej układów zasilania trakcji tramwajowej (1). Technika Transportu Szynowego 7-8/2001, s. 5965

[5.] Szelag A., Drażek Z., Maciołek T., Patoka M,Studium układu zasilania trakcji tramwajowej Tramwajów Warszawskich sp. z o.o.", Praca Zakładu Trakcji Elektrycznej PW na zlecenie Tramwajów, Warszawskich, Warszawskich, Warszawa, 2010-2011

[6.] Szelag A. - Zwiększanie efektywności energetycznej transportu szynowego. Technika Transportu Szynowego 12/2008, s.12-18 